\title{
EDITORAÇÃO CIENTÍFICA: ALÉM DE UMA LENDA
}

Maria Lúcia Boarini

Nas vagas recordações dos meus cinco anos corria entre meus pares a lenda segundo a qual de sete em sete anos algo de muito bom ou muito ruim acontecia em nossas vidas. A expectativa aumentava com a proximidade dos sete anos, e, ao chegarem estes e nada acontecer, aliviados, pensávamos que as surpresas houvessem sido adiadas para os múltiplos de sete, ou seja, para os quatorze, vinte e um anos e daí por diante. Assim o tempo foi passando e transformando aquela grande preocupação em uma leve lembrança.

Superstições à parte, este fato, a nosso ver, já apontava para algo que ainda não tínhamos plenas condições cognitivas para entender: o tempo como um dos importantes fatores no traçado dos rumos de nossa existência. Aliás, o tempo e o trabalho são decantados em prosa e verso, de longa data. Podemos ilustrar esta afirmação com a história de Jacó, personagem bíblico, que, para conseguir casar com sua amada Raquel, para o pai desta e seu tio, Labão, arduamente trabalhou durante duas vezes sete anos (Gn 29,13-30). Determinação, perseverança e muito trabalho pavimentaram o tempo e o caminho que levaram Jacó à mulher amada.

Enfim, esta digressão foi estimulada por três ótimas notícias que Psicologia em Estudo tem a oferecer ao leitor. Após sete anos de muito trabalho e superação de grandes dificuldades, que variam desde a busca incessante por recursos até o exercício de todo o trabalho burocrático, por falta de infra-estrutura no trabalho de editoração, fomos aceitos, à base de dados da PsycINFO, na coleção Scientific Eletronic Library Online - SciELO, em comunicado, e, pela segunda vez consecutiva, Psicologia em Estudo está classificada pela Comissão Anpepp/Capes como ANacional, na avaliação dos periódicos científicos produzidos no Brasil. Embora estas instituições dispensem apresentações, vale relembrar que o indexador PsycINFO é organizado pela American Psychological Association e é considerado o mais importante indexador internacional em Psicologia e áreas afins. A SciELO, por sua vez, é uma das mais importantes bibliotecas eletrônicas produzidas no Brasil e abrange uma coleção selecionada de periódicos científicos. Essa biblioteca virtual é mantida através do acordo entre as instituições Fapesp, Bireme e Capes. E a Comissão da Anpepp/Capes é constituída por um grupo de professores indicados pela Associação Nacional de Pesquisa e Pós-Graduação-Anpepp e pela Capes para avaliar a qualidade dos periódicos científicos publicado em âmbito nacional e utilizados pela pós-graduação para a divulgação de sua produção cientifica.

Este é um acontecimento deveras importante, pois, como afirma Coimbra Jr. (2003, p. 3),

ao longo do tempo e numa escala global, a inclusão de um título por parte dos indexadores ditos mais tradicionais passou a ser vista como um atributo que confere prestígio à publicação. A avaliação da qualidade de um determinado periódico não foi uma intenção daqueles que iniciaram os sistemas de informação bibliográfica em ciência; contudo, nos dias de hoje, essa associação entre indexação e avaliação de qualidade esta cada vez mais corrente (grifo nosso).

E esta importância generaliza-se para todos os segmentos que dão a cor e o tom do periódico Psicologia em Estudo, daí merecer destaque no editorial. Senão vejamos.

Ao ter o seu texto incluído em uma base de dados com esta dimensão, o autor dará mais visibilidade às suas produções, o que pode significar que seus textos contam com a probabilidade de serem lidos por um maior número de pesquisadores e, em decorrência, podem ocorrer interessantes intercâmbios. Por outro lado, cumpre considerar que, pelo grande número de periódicos produzido, a indexação, que a principio não exigia nenhuma seleção, passa a ter critérios para o aceite. Critérios bastante exigentes, como é o caso dos serviços em pauta, digase de passagem. Isto significa que estar incluído na PsycINFO e na SciELO constitui o reconhecimento do padrão de qualidade que conseguimos manter durante estes sete e trabalhosos anos de determinação e certeza de estar contribuindo para a divulgação e intercâmbio de idéias da comunidade científica. 
Não obstante, na empolgação destas novas indexações e classificação, não podemos perder de vista o antigo e sábio adágio popular "Uma andorinha só não faz verão". Com isto estamos querendo dizer que o prestígio alcançado por este periódico não aconteceu por conta própria, como em um passe de mágica. Como sempre afirmamos, tal empreitada não se leva a cabo solitariamente. Trata-se de um trabalho coletivo, em que, de maneira similar a uma orquestra, todos os seus integrantes têm que dar o seu tom, para que, afinados, no conjunto se materialize a melodia. Desta forma, devemos tributo aos autores que nos confiaram suas reflexões (publicadas ou não); ao Conselho Editorial e Consultores $a d$ hoc, que, com disponibilidade e seriedade, garantem a qualidade dos textos publicados; aos nossos revisores (português e inglês), que destacam o brilho destes idiomas; ao "nosso" diagramador, que, com seu olhar técnico e estético, vem garantindo a tão apreciada apresentação deste periódico; a equipe de organização e apoio, que, atendendo dos pequenos aos grandes detalhes, vem contribuindo na pavimentação dos caminhos percorridos. Agradecemos, ainda, à Comissão Anpepp/Capes, que, por sua exigência, indica-nos a necessidade de não perder de vista o rigor na observância de critérios na publicação de um periódico cientifico. Assim, deixamos aqui expressos os nossos agradecimentos a este conjunto de profissionais, que vem, ano a ano, facilitando o percurso de tão tortuosos caminhos e contribuindo para a manutenção e o alcance de novas conquistas no campo da editoração cientifica. Estas conquistas, todavia, longe de nos manter "deitados em berço esplêndido", indicam-nos que a responsabilidade se potencializa a cada patamar alcançado. Responsabilidade que traz em seu bojo muito trabalho e a necessidade de determinação e certeza do caminho que levará ao objetivo perseguido. Assim, retomando o início deste editorial, diremos que pensar que as mudanças ocorrem de sete em sete anos por conta própria e que desta forma se mantêm por novos sete anos é, de fato, uma bela fantasia infantil. Hoje temos uma certeza: manter uma revista de qualidade reconhecida só é possível com a determinação e a certeza de Jacó.

\section{REFERÊNCIAS}

Coimbra Jr., Carlos E. A. (1999). Scientific production in public health and the international literature bases. Cad. Saúde Pública, 15 (4), $883-$ 888. Disponível em: <http://www.scielo.br/scielo.php?script=sci_arttext\&pid=S0102-311X1999000400022\&lng=en\&nrm=iso>. (Acessado em 22/06/2003) 